\title{
THE CHOICE OF THE OPTIMAL $p H$ RANGE FOR A PARENTERAL DRUG BASED ON SALTS OF ALDONIC AND POLYCARBOXYLIC ACIDS
}

\author{
N.V.Begunova \\ National University of Pharmacy \\ Key words: complexation; $p H$; stability; stability constant; primary packing
}

\begin{abstract}
Studies on creation of a new solution for infusion containing the complex compound obtained by the reaction of alkaline earth salt of aldonic and alkali salts of polycarboxylic acids have been carried out. Based on the study of physical and chemical properties of the initial reagents and factors affecting the completeness of complexation, the optimal reaction conditions have been determined. Conditional constants of the complex formation have been calculated. The possibility to obtain a stable complexonate solution in the presence of other substances, and at different $\mathrm{pH}$ values have been evaluated. Percentage of the complex in solution with these $\mathrm{pH}$ has been calculated. The value of the medium acidity, which provides the complexation effect at least $99 \%$, has been determined. The study in selecting the acceptable $\mathrm{pH}$ range of the solution with the concentration calculated on the basis of a given single therapeutic dose and the molar ratio of the initial ingredients has been carried out. The optimal pH range - from 6.2 to 6.5 has been determined. The stability of the experimental batches of the drug placed in bottles of two types of glass and sealed with stoppers of two types has been observed. The quality of the drug solution in the process of preparation, during the entire technological cycle and during storage in the primary packing has been examined. It has been found that the quality parameters of a freshly prepared solution during and at the end of the regulated period of storage in all types of the primary packing corresponds to the parameters of normative documents. These data confirm the acceptability of the $\mathrm{pH}$ range proposed for providing the reaction efficiency and the drug stability. The studies carried out have revealed the limits for one of the most important variable pharmaceutical parameters $(\mathrm{pH})$, and it will be used at the next stages of pharmaceutical development.
\end{abstract}

The drug being developed is a solution of a bimetallic complex obtained presumably by the interaction of alkaline and alkaline earth metals salts with aldonic and polycarboxylic acids (hereinafter "The Complex"). The necessity of its creation is conditioned by the data indicating the presence of properties allowing to use this compound in the treatment of neoplastic diseases with greater efficiency than the known compounds with the similar pharmacological activity. Thus, the Complex blocks the cell proliferation in cases of non-small-cell lung carcinoma 4.5 times more efficiently than a well-known drug Oxaliplatin. Moreover, the antiproliferative activity of the drug lasts longer, and it allows to decrease the therapeutic dose and toxic load. The Complex toxicity has been found to be 200 times less than the one of the prototype.

Creation of a drug involves carrying out the pharmaceutical development (PD), which includes the choice of the composition, technology development, determination of the quality criteria and limits for variable pharmaceutical parameters that provide stability during the process of manufacture and while storing $[3,12]$.

The peculiarity of obtaining this drug is the fact that the active ingredient (AI) is obtained by carrying out the complexation reaction in the process of solution preparation. Thus, one of the initial PD stages was the study of the reaction conditions and determination of the acceptable parameters of the process, including $\mathrm{pH}$ $[3,5,12]$. The aim of our work was to determine the optimal $\mathrm{pH}$ range, which provides the specified direction of the reaction and its maximum quantitative effect, maintains the solution stability and is pharmacologically acceptable.

\section{Materials and Methods}

The objects of the study were salts of aldonic acid (AA) and polycarboxylic acid (PA), solution of the Complex on their basis and the $\mathrm{pH}$ level.

The qualitative and quantitative control of the samples of the Complex and the drug on its basis in the primary packing was carried out during the research work. The quality parameters and methods of determination are described in the $\mathrm{SPhU}$ [2] and the drug normative documents (ND).

\section{Results and Discussion}

Physical, chemical and technological properties of the alkali PA salt and alkaline earth AA salt were studied for choosing the composition and technology for obtaining the drug.

Aldonic acids have the general structure $\mathrm{HOCH}_{2}[\mathrm{CH}(\mathrm{OH})]_{n} \mathrm{COOH}$, and are readily soluble in water. The ionization constant of the AA salt studied is $-1.4 \cdot 10^{-4}$, pKa $3.6[1,7]$. It exhibits the properties that are typical for polyoxyacids. The presence of pentacyclic $\gamma$-lactone and hexacyclic $\delta$-lactone in water solutions of the acid is caused by the ability for lactonization; their quantitative ratio depends on the temperature and $\mathrm{pH}$ value $[6,8,11]$. 
Table 1

Relative stability constants and the Complex concentration at different $\mathrm{pH}$ values

\begin{tabular}{|c|c|c|c|c|c|}
\hline \multirow{2}{*}{$\mathrm{pH}$} & \multicolumn{4}{|c|}{$K^{\prime}\left(M Y^{n-4}\right)=K\left(M Y^{n-4}\right) \cdot a\left(Y^{4-}\right)$} & \multirow{2}{*}{$\begin{array}{c}{\left[\mathrm{MY}^{\mathrm{n}-4}\right]=\mathrm{K}^{\prime}\left(\mathrm{MY}^{\mathrm{n}-4}\right) \cdot\left[\mathrm{M}^{\mathrm{n}+}\right] \cdot\left[\mathrm{Y}^{4}\right]} \\
{\left[M \mathrm{Y}^{\mathrm{n}-4}\right], \%}\end{array}$} \\
\hline & $K\left(M Y^{n-4}\right)$ & $a\left(Y^{4-}\right)$ & $\mathrm{K}^{\prime}\left(M Y^{\mathrm{n}-4}\right)$ & $\lg K^{\prime}\left(M Y^{n-4}\right)$ & \\
\hline 4 & $5 \cdot 10^{10}$ & $3.6 \cdot 10^{-9}$ & $1.8 \cdot 10^{2}$ & 2.25 & 92.82 \\
\hline 5 & $5 \cdot 10^{10}$ & $3.5 \cdot 10^{-7}$ & $1.8 \cdot 10^{4}$ & 4.26 & 99.26 \\
\hline 6 & $5 \cdot 10^{10}$ & $2.2 \cdot 10^{-5}$ & $1.1 \cdot 10^{6}$ & 6.04 & 99.90 \\
\hline 7 & $5 \cdot 10^{10}$ & $4.8 \cdot 10^{-4}$ & $2.4 \cdot 10^{7}$ & 7.38 & 99.98 \\
\hline 8 & $5 \cdot 10^{10}$ & $5.4 \cdot 10^{-3}$ & $2.7 \cdot 10^{8}$ & 8.43 & 99.99 \\
\hline 9 & $5 \cdot 10^{10}$ & $5.2 \cdot 10^{-2}$ & $2.6 \cdot 10^{9}$ & 9.41 & 100.00 \\
\hline
\end{tabular}

The following feature is typical for the carboxylic group. This is the ability of salt formation, including with alkali, alkaline earth and transition metals. The structure of the salts: $\left[\mathrm{HOCH}_{2}[\mathrm{CH}(\mathrm{OH})]_{n} \mathrm{COO}^{-}\right]_{x} \mathrm{Me}^{\mathrm{x}+}$. This AA and its derivatives are used as complexing agents, especially when the metal cations are able not only to substitute the active hydrogen atoms of its functional groups, but also to form coordinate bonds. These are the alkaline earth metal ions (s-elements) $-\mathrm{Ba}^{2+}$, $\mathrm{Mg}^{2+}, \mathrm{Ca}^{2+}$. It is exactly the AA calcium salt that takes part in the Complex formation. Its solubility at $30^{\circ} \mathrm{C}$ is about $40 \mathrm{~g} / 1$ [4, 6-8, 11].

Although $\mathrm{Ca}^{2+}$ salts are able to coordinate hydroxyacids, these complexes are not stable enough. The stability constant of calcium aldonate is rather low (approximately $16, \lg \mathrm{K}=1.2$ ), and in the presence of other organic polydentate complexing agents, even with high $\mathrm{Ca}^{2+}$ concentration, their binding into a complex with aldonate may be disturbed and lead to formation of a complex compound with other ligand $[11,14]$. This exactly feature was used by us for the Complex formation.

Polycarboxylic acids have the following general structure: $(\mathrm{HOOC})_{\mathrm{n}} \mathrm{R}$, where $\mathrm{R}$ - is a hydrocarbon radical. PA, which salt takes part in the Complex formation, is also an ethylene diamine derivative, and can be represented as: $(\mathrm{HOOC})_{4}\left(\mathrm{CH}_{2} \mathrm{~N}_{2}\right)_{2}$ (then also $\mathrm{H}_{4} \mathrm{Y}$ ). It is able to form intracomplex compounds with metal cations due to the valence bonds with carboxylic groups and the coordinate bonds with nitrogen lone electron pairs.

Constants of the first two stages of $\mathrm{PA}\left(\mathrm{H}_{4} \mathrm{Y}\right)$ dissociation far exceed the following two: $\mathrm{K}_{\mathrm{a} 1}=1 \cdot 10^{-2}\left(\mathrm{pK}_{\mathrm{a} 1}=\right.$ $2.0), \mathrm{K}_{\mathrm{a} 2}=2.1 \cdot 10^{-3}\left(\mathrm{pK}_{\mathrm{a} 2}=2.7\right), \mathrm{K}_{\mathrm{a} 3}=6.9 \cdot 10^{-7}\left(\mathrm{pK}_{\mathrm{a} 3}=6.2\right)$, $\mathrm{K}_{\mathrm{a} 4}=5.5 \cdot 10^{-11}\left(\mathrm{pK}_{\mathrm{a} 4}=10.3\right)[1,8,7]$. It follows that mainly $\mathrm{H}_{2} \mathrm{Y}^{2-}$ anions exist in the neutral medium. With the solution $\mathrm{pH}$ increase ions $\mathrm{HY}^{3-}$ and $\mathrm{Y}^{4-}$ start to form, moreover, the latter - in the highly alkaline medium with $\mathrm{pH}>11$. A disodium PA salt is used for the Complex formation since it is much better soluble in water than the acid is. The reaction between a calcium ion and the salt, as a result of which the anion forms a tetrahedral complex with a double-charged metal ion, can be written as equation 1 :

$$
\mathrm{Ca}^{2+}+\mathrm{Na}_{2} \mathrm{H}_{2} \mathrm{Y} \leftrightarrow \mathrm{Na}_{2} \mathrm{CaY}+2 \mathrm{H}^{+}
$$

Several features of the reaction should be mentioned: complexes of a single composition with the ratio of 1:1 (metal:ligand) are formed; the reaction is reversible, and the balance can be shifted by varying the $\mathrm{pH}$ - acidifying will shift the balance to the initial reagents, while adding an alkali - to the right with the complexonate formation; the reaction should be carried out with maintaining the $\mathrm{pH}$ optimum level determined by the complexonate stability constant $\mathrm{K}$ (or $\beta$ ).

Based on the known stability constants of the complex equation $[1,6,8,14]$ it is possible to calculate the value when the complexing reaction proceeds with sufficient completeness, i.e. $99.99 \%$, in the following way:

$$
\begin{gathered}
\mathrm{K}\left(\mathrm{MY}^{\mathrm{n}-4}\right)=\frac{\left[\mathrm{MY}^{\mathrm{n}-4}\right]}{\left[\mathrm{M}^{\mathrm{n}+}\right] \cdot\left[\mathrm{Y}^{4-}\right]}= \\
=\frac{0,9999}{1 \cdot 10^{-4} \cdot 1 \cdot 10^{-4}}=10^{8} .
\end{gathered}
$$

The true concentration constant of formation (stability) does not depend on the concentration and $\mathrm{pH}$. But the medium acidity and additional complexing agents affect the complexing completeness. This is taken into account using relative stability constants, which help to estimate if it is possible to obtain a stable complexonate in the medium with a certain $\mathrm{pH}$ and the presence of other compounds.

The $\mathrm{pH}$ influence is taken into account using the competing reaction coefficient $\alpha\left(\mathrm{Y}^{4-}\right)$, which reflects the ligand protoning. Knowing the $\mathrm{K}$ and $\alpha\left(\mathrm{Y}^{4-}\right)$ values at the given $\mathrm{pH}$ it is possible to calculate the relative stability constant of the complexonate K', and comparing it with $10^{8}$ make a conclusion about the stability of the complex studied. The $\mathrm{K}$ value for the complex $\mathrm{CaY}^{2-}$ is $5 \cdot 10^{10}, \operatorname{lgK}=10.7$, the value $\alpha\left(\mathrm{Y}^{4}\right)$ for different $\mathrm{pH}$ can also be found in literature $[1,6,8,14]$.

The $\mathrm{K}^{\prime}$ values were calculated for different $\mathrm{pH}$ values, and then the percentage of the Complex in the solution with such $\mathrm{pH}$ values was calculated. The formulas and results of calculations are given in Tab. 1 . With its data it is shown that the Complex stability reaches $\mathrm{K}^{\prime}>10^{8}$ values in the alkaline media with $\mathrm{pH} 8$ and higher. With the $\mathrm{pH}$ decrease the complexing process may pass not completely. However, the concentrations of the Complex calculated at different $\mathrm{pH}$ values allow to make a conclusion that the concentration over $99 \%$ indicating the sufficient completeness of the reaction is already achieved after $\mathrm{pH} 5$, and is $99.9 \%$ at $\mathrm{pH} 6$. 


\section{$\left[\mathrm{HOCH}_{2}[\mathrm{CH}(\mathrm{OH})]_{n} \mathrm{COO}\right]_{2} \mathrm{Ca}^{2+}+\left[(\mathrm{HOOC})_{2}\left(\mathrm{CH}_{2} \mathrm{~N}_{2}\right)_{2}\left(\mathrm{COO}^{-}\right)_{2}\right] \mathrm{Na}_{2}^{+} \longrightarrow$}

\section{$\longrightarrow \mathrm{Ca}^{2+}\left[\left(\mathrm{CH}_{2} \mathrm{~N}_{2}\right)_{2}\left(\mathrm{COO}^{-}\right)_{4}\right] \mathrm{Na}^{+}{ }_{2}+2\left[\mathrm{HOCH}_{2}[\mathrm{CH}(\mathrm{OH})]_{n} \mathrm{COO}\right]+2 \mathrm{H}^{+}$}

Fig. The scheme of the complexing reaction.

Then often the solution contains molecules or ions that are able to form complexes with ions of the metal, which takes part in the Complex formation. The influence of additional complexes is taken into account with the competing reaction coefficient $\alpha\left(\mathrm{M}^{\mathrm{n}+}\right)$. Knowing its value, $\mathrm{K}^{\prime \prime}$ is determined - the relative stability constant in case of an additional metal ion complexing using formula 3 :

$$
\mathrm{K}^{\prime \prime}\left(M Y^{\mathrm{n}-4}\right)=\mathrm{K}\left(\mathrm{MY}^{\mathrm{n}-4}\right) \cdot \alpha\left(\mathrm{Y}^{4-}\right) \cdot \alpha\left(\mathrm{M}^{\mathrm{n}+}\right) .
$$

Taking into account a great difference in the stability constants' values of the complex of calcium with PA $\left(5 \cdot 10^{10}, \operatorname{lgK}=10.7\right)$ and with AA $(16, \operatorname{lgK}=1.2)$, we made a conclusion that the presence of AA anions in the solution would not affect the Complex's stability. Thus, $\mathrm{K}^{\prime \prime}\left(\mathrm{MY}^{\mathrm{n}-4}\right)=\mathrm{K}^{\prime}\left(\mathrm{MY}^{\mathrm{n}-4}\right)$, and the data from the column 6 of Table 1 do not need any correction.

Based on the physical and chemical properties of the reagents and the calculations conducted we composed a predictable scheme of the reaction (Fig.).

As a result of the interaction $\mathrm{H}^{+}$ions are transferred into the solution, $\mathrm{pH}$ of the solution decreases, and it can lead to the reaction shift to the left causing destruction of the Complex. To prevent this process the $\mathrm{pH}$ should be maintained at the level not lower than 8-9 (Tab. 1). For the parenteral route of the drug administration the more optimal $\mathrm{pH}$ level is the one close to the blood $\mathrm{pH}$ $(\sim 7.4)$, but there are solutions for infusion with a slightly acidic medium, which is due to the AI properties and pharmacological purpose $[5,10,13,15]$. It is worth taking into account that the concentration of $\mathrm{H}^{+}$ions plays an important role in potentiating/inhibiting the processes of interaction of the solution and primary packing materials (glass or polymer containers, stoppers, etc.) $[5,9]$.

Therefore, the research work on selection of a suitable $\mathrm{pH}$ level was carried out. Solutions with the concentration corresponding to the given single therapeutic dose and the molar ratio of the initial reagents $-2: 1$ (aldonate:polycarbonate) were prepared for that purpose.

The initial $\mathrm{pH}$ range set in the solution was 4.0-5.0. This is explained by the free $\mathrm{H}^{+}$ions appearance as the reaction products. Moreover, the AA anions and the excess of calcium aldonate are present conditioned by the ratio of 2:1. This $\mathrm{pH}$ level is insufficient for the Complex stability maintenance. Thus, the correction to the minimal level 5.0 (Tab. 1) or better around 7.4 is necessary. But it should also be taken into consideration that the presence of an excess of the initial reagents, according to the principle of Le Chatelier-Brown $[5,6,8]$, will prevent the reaction reversibility.

For selection of the $\mathrm{pH}$ level that would provide the stability maintenance and suitable for introduction of the solution into the bloodstream, the batches with different $\mathrm{pH}$ achieved by adding alkaline agents, out of which sodium hydroxide solution containing ions of the same name with reagents was chosen, were tested. Different temperature and time regimes were studied, the additional $\mathrm{pH}$ correction at different preparation stages was carried out, etc. The results of the study are given in Tab. 2 .

It was found that in the samples with $\mathrm{pH}$ 7.2-7.4 and higher within the time from several hours to a day the $\mathrm{pH}$ value was significantly reduced. With the $\mathrm{pH}$ value 8.0 and higher the solution gained a yellow tint under the effect of temperature. The low pH level (5.0 and lower) is undesirable since it leads to the complex stability decrease and significantly differs from the blood $\mathrm{pH}$ level. By changing the medium acidity the optimal $\mathrm{pH}$ range was determined, which was from 6.2 to 6.5.

To confirm this result the Complex solution stability was studied not only in the process of preparation and in carrying out the entire technological cycle, but also during the drug storage in the primary packing. The solution stability in glass bottles is caused by its prolonged contact with the glass and the stopper material. Mechanical inclusions may appear in the solution, their absence is strictly regulated for solutions for infusion $[2,3,5]$. The interaction of the solution with glass and a stopper may cause the changes of other physical and chemical quality parameters and lead to the inconsistency of the final product to the ND requirements.

Experimental batches of the drug in $100 \mathrm{ml}$ glass bottles made of NC-2 and MTO glass grades with rub-

Table 2

Dynamics of the $\mathrm{pH}$ changes in the Complex solutions

\begin{tabular}{|c|c|c|c|c|c|}
\hline \multirow{2}{*}{$\begin{array}{c}\text { No. of the } \\
\text { batch }\end{array}$} & \multicolumn{5}{|c|}{ Solution $\mathrm{pH}$} \\
\hline & freshly prepared (A) & in a couple of hours & in a day & sterilized (B) & difference (A-B) \\
\hline 1 & 5.53 & $5.32(1.5$ h.) & 5.20 & 5.17 & 0.36 \\
\hline 2 & 6.00 & $5.63(2 \mathrm{~h})$. & 5.63 & 5.60 & 0.40 \\
\hline 3 & 6.40 & $5.98(2 \mathrm{~h})$. & 5.98 & 6.00 & 0.40 \\
\hline 4 & 7.15 & $7.03(2 \mathrm{~h})$. & 6.00 & 6.0 & 1.15 \\
\hline 5 & 7.55 & $7.39(1 \mathrm{~h})$. & 6.95 & 6.95 & 0.60 \\
\hline 6 & 8.01 & $7.30(1 \mathrm{~h})$. & 6.80 & 6.75 & 1.26 \\
\hline
\end{tabular}


Table 3

Control of $\mathrm{pH}$ changes of the Complex solution when storing

\begin{tabular}{|c|c|c|c|c|c|c|}
\hline \multirow{3}{*}{$\begin{array}{l}\text { No. } \\
\text { of the } \\
\text { batch }\end{array}$} & \multirow{3}{*}{$\begin{array}{l}\text { The glass } \\
\text { grade }\end{array}$} & \multirow{3}{*}{ Type of the stopper } & \multicolumn{4}{|c|}{ The solution $\mathrm{pH}$ (standard) } \\
\hline & & & \multirow{2}{*}{$\begin{array}{l}\text { Freshly prepared } \\
\text { solution }(6.2-6.5)\end{array}$} & \multicolumn{3}{|c|}{ Final product (5.5-6.5) } \\
\hline & & & & Initial data & 6 months & 12 months \\
\hline \multirow{4}{*}{7} & \multirow{2}{*}{ NG-2 } & $52-369 / 1$ & 6.21 & 5.86 & 5.84 & 5.86 \\
\hline & & V9263,FM140/0 & 6.21 & 5.83 & 5.83 & 5.85 \\
\hline & \multirow{2}{*}{ MTD } & $52-369 / 1$ & 6.21 & 5.85 & 5.84 & 5.84 \\
\hline & & V9263,FM140/0 & 6.21 & 5.85 & 5.86 & 5.85 \\
\hline \multirow{4}{*}{8} & \multirow{2}{*}{ NG-2 } & $52-369 / 1$ & 6.33 & 5.98 & 6.00 & 5.97 \\
\hline & & V9263,FM140/0 & 6.33 & 5.98 & 5.96 & 5.95 \\
\hline & \multirow{2}{*}{ MTD } & $52-369 / 1$ & 6.33 & 5.98 & 5.98 & 5.98 \\
\hline & & V9263,FM140/0 & 6.33 & 5.97 & 5.98 & 5.96 \\
\hline \multirow{4}{*}{9} & \multirow{2}{*}{ NG-2 } & $52-369 / 1$ & 6.47 & 6.12 & 6.12 & 6.11 \\
\hline & & V9263,FM140/0 & 6.47 & 6.12 & 6.10 & 6.12 \\
\hline & \multirow{2}{*}{ MTD } & $52-369 / 1$ & 6.47 & 6.11 & 6.11 & 6.09 \\
\hline & & V9263,FM140/0 & 6.47 & 6.12 & 6.14 & 6.12 \\
\hline
\end{tabular}

ber stoppers of 52-369/1 grade ("Kyivhuma", Ltd.) and V9263, FM 140/0 grade (Helvoet Pharma, Belgium) were tested. The results of the $\mathrm{pH}$ monitoring are shown in Tab. 3. Control of the quality parameters of the freshly prepared solution and while storing has shown that the samples of batches 7-9 in the packing types indicated meet the ND requirements such as transparency, colour, mechanical inclusions, quantitative content by their physical and chemical characteristics. The rest indicators also meet the ND requirements. In the bottles with 52-369/1 grade stoppers on the butylcaoutchouc basis a specific smell appears (thiuram decomposition), and it can be prevented by special preliminary stoppers processing and siliconizing. In the bottles closed with V9263, FM 140/0 stoppers the smell is not developed. The indicator "Smell" is not regulated by the ND.
Thus, the optimal $\mathrm{pH}$ level that can provide stability of the Complex solution on the basis of AA and PA salts and suitability of the primary packing for the drug storage has been experimentally confirmed.

CONCLUSIONS

1. Physical, chemical and technological properties of the initial reagents have been studied. The conditions of the reaction course between them and the factors affecting the complexing completeness have been determined.

2 . The optimal $\mathrm{pH}$ level for the complex formation and maintenance of physical and chemical stability of the parenteral drug on the basis of aldonic and polycarboxylic salts has been theoretically and experimentally substantiated.

3 . The effect of the primary packing on the drug stability during storage has been studied.

\section{REFERENCES}

1. Гороновский И.Т., Назаренко Ю.П., Некряч Е.Ф. Краткий справочник по химии. - 5-е изд. - К.: Наук. думка, 1987. - 830 c.

2. Держсавна фармакопея України / Державне підприємство «Науково-експертний фармакопейний центр». 1-е вид. - Х.: ООО РИРЕГ, 2001. - 531 c.

3. Лікарські засоби. Фармацевтична розробка (ICH Q8). Настанова СТ-Н МОЗУ 42-3.0:2011.- К.: МОЗ України, 2011. - 33 с.

4. Пат. 2132878 Россия, МПК С 12 Р7/40, С 12 Р7/48, С 12 N1/14. - Заявл.: 06.01.1998. Опубл.: 10.07.1999. Бюл. №31. - 13 c.

5. Технология и стандартизаиия лекарств / Под ред. В.П.Георгиевского, Ф.А.Конева. - Т. 2. - Х.: ИГ РИРЕГ, 2000. - 784 c.

6. Черных В.П., Зименковский Б.С., Гриценко И.С. Органическая химия: учеб. - 2-е изд., испр. и доп. - Х.: Изд-во НФаУ; Оригинал, 2007. - 776 с.

7. Aldrich Chemistry 2012-2014: Handbook of Fine Chemicals / Sigma-Aldrich Corporation. - Sigma-Aldrich (USA), 2011. - $3216 p$.

8. Darrell D. Ebbing, Steven D. Gammon. General Chemistry. - $9^{\text {th }}$ ed. - Cengage Learning (USA), 2009. - $1030 p$.

9. Driscoll D.F., Silvestri A.P., Bistrian B.R., Mikrut B.A. // Am. J. of Health-System Pharmacy. - 2007. - T. 64, №4. - C. 396-403.

10. Electronic Medicines Compendium (емC) [Електронний pecypc]-Pежим достуny: www.resourceclinical. com/parenteral-drug-ther 
11. Fasman Gerald D. Handbook of Biochemistry and Molecular Biology. - 3th ed. - Vol. 1. - CRC Press (USA), 1976. $-310 p$.

12. Q8: Pharmaceutical Development. ICH Harmonized Tripartite Guideline/-Peжcuм docmyny: http://www.ich.org/

13. Rote Liste. - Frankfurt/Main: Verlag, 2007. - 559 p.

14. Skoog D.A., West D.M, Holler F.J. Fundamentals of Analytical Chemistry. - 5th ed. - New York: Saunders College Publishing, 1988. - 752 p.

15. The British Medical Association New Guide to Medicines \& Drugs. - 8th ed. - London: Dorling Kindersley, 2011. $-512 p$.

\section{ВИБІР ОПТИМАЛЬНИХ МЕЖ РН ДЛЯ ПАРЕНТЕРАЛЬНОГО ПРЕПАРАТУ НА ОСНОВІ СОЛЕЙ АЛЬДОНОВОЇ І ПОЛІКАРБОНОВОЇ КИСЛОТИ \\ Н.В.Бєгунова}

Ключові слова: комплексоутворення; рH; стабільність; константа стійкості; первинне пакування

Проведено дослідження зі створення нового парентерального препарату, що містить комплексну сполуку, отриману в результаті взаємодії лужноземельної солі альдонової та лужної солі полікарбонової кислоти. На підставі вивчення фрізико-хімічних властивостей вихідних реагентів і фракторів, що впливають на повноту комплексоутворення, були визначені оптимальні умови перебігу реакції. Розраховані умовні константи утворення комплексу. Оцінено можливість отримання стійкого комплексонату в розчині при наявності інших речовин і при різних значеннях $\mathrm{pH}$. Обчислено процентний вміст комплексу в розчині з такими рН. Визначено значення кислотності середовища, яке гарантує ефрект комплексоутворення не менше 99\%. Проведено дослідження з підбору підхожого інтервалу рН розчину, концентрація якого розрахована на підставі заданої разової терапевтичної дози і мольного співвідношення вихідних інгредієнтів. При варіюванні кислотності реакційного середовища визначено оптимальний діапазон рH - від 6,2 до 6,5. Проведено спостереження за стабільністю дослідних серій препарату, поміщеного в пляшки з двох видів скла, закупорені пробками двох видів. Вивчено якість розчину лікарського препарату в процесі приготування, при проведенні всього технологічного циклу і при зберіганні в первинному пакуванні. Встановлено, що показники якості розчину свіжоприготованого, під час і після закінчення регламентованого терміну зберігання та у всіх видах первинного пакування відповідають показникам нормативної документації. Отримані дані підтверджують прийнятність запропонованого діапазону рН для забезпечення ефективності реакції і стабільності лікарського препарату. В результаті досліджень встановлені та обгрунтовані прийнятні межі для одного з найважливіших змінних фрармацевтичних параметрів $(\mathrm{pH})$, що буде використано на наступних етапах фрармацевтичної розробки.

\section{ВЫБОР ОПТИМАЛЬНЫХ ПРЕДЕЛОВ РН ДЛЯ ПАРЕНТЕРАЛЬНОГО ПРЕПАРАТА НА ОСНОВЕ СОЛЕЙ АЛЬДОНОВОЙ И ПОЛИКАРБОНОВОЙ КИСЛОТЫ Н.В.Бегунова}

Ключевые слова: комплексообразование; pH; стабильность; константа устойчивости; первичная упаковка

Проведены исследования по созданию нового парентерального препарата, содержащего комплексное соединение, полученное в результате взаимодействия щелочноземельной соли альдоновой и щелочной соли поликарбоновой кислоты. На основании изучения фризико-химических свойств исходных реагентов и фракторов, влияющих на полноту комплексообразования, были определены оптимальные условия протекания реакции. Рассчитаны условные константы образования комплекса. Оценена возможность получения устойчивого комплексоната в растворе при наличии других веществ и при различных значениях $\mathrm{pH}$. Вычислено процентное содержание комплекса в растворе с такими рН. Определено значение кислотности среды, гарантирующее эфффрект комплексообразования не менее 99\%. Проведены исследования по подбору приемлемого интервала $\mathrm{pH}$ раствора, концентрация которого рассчитана на основании заданной разовой терапевтической дозы и мольного соотношения исходных ингредиентов. При варьировании кислотности реакционной среды определен оптимальный диапазон pH - om 6,2 до 6,5. Проведены наблюдения за стабильностью опытных серий препарата, помещенного в бутылки из двух видов стекла, укупоренные пробками двух видов. Изучено качество раствора лекарственного препарата в процессе приготовления, при проведении всего технологического цикла и при хранении в первичной упаковке. Установлено, что показатели качества раствора свежеприготовленного, во время и по окончании регламентируемого срока хранения и во всех видах первичной упаковки соответствуют показателям нормативной документации. Полученные данные подтверждают приемлемость предложенного диапазона рН для обеспечения эфффективности реакции и стабильности лекарственного препарата. В результате исследований установлены и обоснованы приемлемые пределы для одного из важнейших переменных фрармацевтических параметров (pH), что будет использовано на следующих этапах фрармацевтической разработки. 